\title{
Leading and Thriving: How Leadership Education Can Improve First-Year Student Success
}

\author{
Clinton M. Stephens \\ Lecturer for Leadership Education \\ Iowa State University \\ cmsteph@iastate.edu \\ Cameron C. Beatty \\ Lecturer for Leadership Education \\ Iowa State University \\ ccbeatty@iastate.edu
}

\begin{abstract}
Leadership development transforms the lives of many students and leadership educators regularly witness these changes. But little research has articulated what is being taught that facilitates this change, how we can make it happen more often, or how we can measure this change. These transformations contribute to desirable outcomes including student persistence and academic achievement. Leadership studies programs have great potential to contribute to these positive student outcomes especially with first-year students.

Using the Social Change Model of Leadership Development, we delineate how the study of leadership aids students in experiencing these transformations, as defined by Schreiner's Thriving Model, along with example lessons that serve elements in both models. Significant implications are discussed, including greater engagement with first-year students and outreach to at-risk students. This is followed by recommendations for leadership educators and a discussion of future research focus areas.
\end{abstract}

\section{Introduction}

Leadership knowledge, skills, and attitudes that students learn in leadership studies courses have the potential to dramatically shape students' trajectory in college and beyond. The development of their leadership abilities in teamwork, self direction, and community building are highly applicable to their own academic, intrapersonal, and interpersonal thriving in college. But these connections are too often casual, taken for granted, or not realized to the fullest potential. Recent research has documented five malleable factors that contribute to student thriving in college (Schreiner, McIntosh, Kalinkewicz, \& Cuevas, 2013). By way of the Social Change Model (Higher Education Research Institute, 1996), We will discuss how the study of leadership can positively contribute to these five factors in college students. This raises important implications for leadership educators regarding when students first take a course in leadership studies, which students leadership educators target for recruitment, and key campus partners with whom to collaborate to maximize student success. Through applying these insights leadership 
educators can broaden the effects of leadership studies programs to positively change more students' college experiences.

\section{Thriving in College}

We as leadership educators all had that student we worked with who started out with a lack of direction or sense of self. But then we observed them transform into an engaged, purposeful student. It is gradual and imperceptible at first - we did not notice it until the change was well underway - and when we finally noticed we were startled by it. These are the students we gladly stay late to listen to their newest revelations. These are the students for whom we most enjoy writing recommendation letters. Leadership educators get to see such transformations happen more often because our leadership studies courses are catalysts for it.

Laurie Schreiner and her research team describe this phenomena as thriving in college (Schreiner, 2013). Through their work over the past five years they have established a framework and defined the thriving construct as "college students who are fully engaged intellectually, socially, and emotionally" (Schreiner, 2010b, p. 2). Their research shows students who are thriving in college are much more likely to persist to graduation, perceive the tuition they pay as a worthwhile investment, and earn higher grades (Schreiner et al., 2013). Further, thriving students are more likely to civically engage and benefit the greater good and take actions that promote social justice (Schreiner, 2010a).

Therefore the transformation that leadership educators often see occur with students in leadership studies courses is critical to these students' futures. We as leadership educators know this intuitively. But what is it that we are teaching that facilitates this transformation? How can we do this more often? How can we measure this change?

\section{Theoretical Frameworks}

For this article we examine the construct of the Thriving Model (Schreiner, McIntosh, Nelson, \& Pothoven, 2009) through the lens of the most widely used leadership development model used in leadership studies programs (Owen, 2012), the Social Change Model of Leadership Development (Higher Education Research Institute, 1996). We intersect the elements of the two frameworks and highlight the common support between the two at these intersections. First we review each framework, followed by an in-depth discussion of the intersections where studying leadership within the Social Change Model supports students thriving in college.

Thriving Model. Building on the prior work of Seligman (2002), Keyes and Haidt (2003), the thriving construct is an adaptation of their models of flourishing in life. Seligman and Csiksezentmihalyi (2000) advanced that the field of psychology could expand beyond clinical psychology and contribute to the positive well-being of human beings. He theorized this in a model with the key elements he identified as contributing to individuals' flourishing in life (Seligman, 2011). Schreiner extended and focused this model of flourishing in life to the context of college students at institutions of higher education, titling it "thriving in college" (Schreiner, 
2010c).

Schreiner's Thriving Model is comprised of three areas that contribute to students thriving in college: psychological, interpersonal, and academic (Schreiner et al., 2013). These areas are constructed from research in student development and research in positive psychology. Collectively they cover students' intra-personal well-being, the social skills and experiences of students, and the educational context in which students function. Within these three areas, Schreiner delineates five factors that constitute these three areas of thriving: positive perspective, social connectedness, diverse citizenship, academic determination, and engaged learning.

Positive perspective. In the area of psychological thriving, this factor encompasses optimism and an expectation of positive outcomes. Students with high positive perspective report feeling well supported in college. They also report greater satisfaction with experiences in life. These students have a long-term view of events; when setbacks occur they recover more quickly because they can reframe the experience. This optimistic outlook helps them approach challenges with greater confidence. (Schreiner, 2013; Schreiner et al., 2013)

Social connectedness. In the area of interpersonal thriving, this factor demonstrates the strong relationships in students' lives. These students surround themselves with people they trust and supportive friendships. They have people in their lives who listen when they need to talk through challenges they are facing. This connectedness contributes to a sense of belonging to a community larger than oneself. (Schreiner et al., 2013)

Diverse citizenship. Also within the area of interpersonal thriving, this factor reflects the mix of multiple cultures, interests, and perspectives that students regularly encounter in their daily lives. Students strong in this factor has high curiosity and openness to learning from the lived experiences of people around them. Further, this factor also reflects students' desire to contribute to their community. (Schreiner, 2013)

Academic determination. For the area of academic thriving, the first factor is academic determination. This encompasses students' locus of control regarding their academic accomplishments. Students high in academic determination approach their studies with a confidence that they are in charge of their own learning. They are motivated to learn, assured they can accomplish their academic goals. (Schreiner et al., 2013)

Engaged learning. This factor, also within the academic area, refers to the active participation of students in their learning endeavors. Students who are strongly engaged learners have focused attention and mindfulness about their studies. They connect what they are studying with their own lives. Engaged learners are psychologically present in class and while studying. These also might manifest through classroom participation or faculty interactions, however students can practice engaged learning without these outwardly observable behaviors (Schreiner, 2013; Schreiner et al., 2013).

These five factors covering the psychological, interpersonal, and academic areas make up the construct of thriving. When measured using a survey instrument, the five factors are combined to estimate a Thriving Quotient for each student. To date, Schreiner's research has 
demonstrated these factors as predictive of desirable outcomes. Students' Thriving Quotient is highly predictive of their self reported intent to graduate - predicting it more strongly than any student or institutional characteristics measured as well as the students' collegiate experiences measured. Students' college GPA was most strongly predicted by their high school GPA, no surprise, but their Thriving Quotient was the strongest predictor of their post-enrollment experiences. Satisfaction with the tuition, a proxy for satisfaction with the institution, was predicted of course by first-generation status and family income-but of students' postenrollment experiences their Thriving Quotient was the strongest predictor (Schreiner et al., 2013).

On whole, the Thriving Model is as strong of a predictor of desirable outcomes as the students' demographic and pre-matriculation measures. This finding is important because we cannot change the race, gender, first-generation status, or high school GPAs of college students-yet these measures significantly contribute to desirable outcomes. What we can change, their post-matriculation experiences. These can contribute to students thriving in college. The Thriving Model provides us with a tool with which to measure students' college experiences.

Next we will examine the Social Change Model and then discuss how it can be applied as a tool to contribute toward increasing students' thriving in college experiences.

Social Change Model. The Social Change Model of Leadership Development (Higher Education Research Institute, 1996) was designed specifically for college students and warrants our focus, given the significant degree to which it influences collegiate leadership programs nationally (Kezar, Carducci, \& Contreras-McGavin, 2006). The model situates leadership as being inherently tied to social responsibility and manifested in creating change that benefits the common good. The Social Change Model is grounded on the importance of increasing individuals' levels of self-knowledge and abilities to work collaboratively. This is accomplished by fostering growth across seven critical values: Consciousness of Self, Congruence, Commitment, Collaboration, Common Purpose, Controversy with Civility, and Citizenship. These values, in turn, contribute to the eighth value of change. These values interact synergistically across three dimensions: individual (Consciousness of Self, Congruence, and Commitment), group (Collaboration, Common Purpose, and Controversy with Civility), and societal (Citizenship). The Social Change Model encourages educators in higher education to apply the categories simultaneously to demonstrate to students that the development of leadership is not exclusively an individualized experience, but a process that benefits from a shared collective and collaboration with others.

Individual dimension. The individual dimension serves as a space for students to think intrinsically about their personal beliefs, attitudes, and motivations towards leadership. The first value of the individual dimension, Consciousness of Self, encourages students to be cognizant of things such as attitudes and behaviors that motivate them to take action. Apart from students exploring Consciousness of Self, the Social Change Model suggests that Congruence be developed alongside Consciousness of Self. Congruence argues that one's feelings and behavior should be consistent, honest, and genuine towards others. The final value of the individual 
dimension is Commitment. Commitment is associated with the drive and passion that motivates an individual to serve and support a collective effort.

Group dimension. Students must engage in understanding their own personal motivations for leadership, then begin to reflect on the next dimension, group values: Collaboration, Common Purpose, and Controversy with Civility. Collaboration refers the ability to work with others for a common purpose. This is a very important value of Social Change Model because it emphasizes the necessity and importance of individuals working cohesively as a group to maximize the talents, perspectives, and viewpoints in order to develop creative solutions and actions. The second value within the dimension is Common Purpose. "Recognizing the common purpose and mission of the group helps to generate the high level of trust that any successful collaboration requires" (Higher Education Research Institute, 1996, p. 23).

While Collaboration and Common Purpose seek to unify, the Social Change Model also recognizes that leading as a group can cause disagreements and conflict. Understanding the importance for students to demonstrate respect for difference of opinions and perspectives, the model advances the value controversy with civility. Controversy with Civility attempts to acknowledge the difficulty of having a variety of perspectives and opinions within a group. This means, "... respect for others, a willingness to hear each other's views, and the exercise of restraint in criticizing the views and actions of others" (Higher Education Research Institute, 1996, p. 23).

Societal dimension. The final dimension is for values that comprise the societal/community perspective. Citizenship is the only value within this category. When reviewing the value of Citizenship, it seems to be the culmination of all of the values previous listed. It recognizes that the common purpose of the group must incorporate everyone's wellbeing and values in order to move the group forward.

These seven values, collected into the three dimensions of individual, group, and societal, comprise the Social Change Model and its focus on social responsibility through benefiting the common good. We selected this theory for our framework because of its central role in many leadership studies programs (Owen, 2012) and the focus on personal and growth development towards positive change.

\section{Intersections of Thriving and Leadership}

Connecting these two theories, the Thriving Model has common support from the values in the Social Change Model. Each of the five factors in the Thriving Model can be strengthened when leadership educators facilitate students' learning of leadership abilities that align with values in the Social Change Model. With the Thriving Model's demonstrated relevance to student persistence and achievement, these connections are critical to understanding how leadership education contributes to these positive academic outcomes.

\section{Support of Thriving Model}

Academic determination. Developing students' Academic Determination includes their self confidence that they are in charge of their own lives and can accomplish their own goals. In 
the Social Change Model, this is developed through Consciousness of Self, Congruence, Commitment, and Common Purpose. The first three values, from the Social Change Model's individual dimension, contribute to Academic Determination when developing future academic plans, including goal setting, writing a four-year resume (Hull-Blanks et al., 2005), or describing what their graduation day will be like (Quoidbach, Wood, \& Hansenne, 2009; Suddendorf \& Busby, 2005). Each of these activities support students in articulating who they want to be and working to fulfill that vision. Further, students learning Common Purpose through activities such as The River Crossing (Reardon, 2003) helps them when working in academic teams to set the team's vision and have the confidence that the team can work effectively to accomplish their academic goals. Together, these four values of the Social Change Model support students' Academic Determination.

Engaged learning. Students strong in Engaged Learning are active participants, connecting their studies with their own lives. This factor of the Thriving Model is supported by many aspects of leadership education when using the Social Change Model-leadership educators strive to inspire students from passively observing to actively participating in leadership, and this closely aligns with Engaged Learning. The Social Change Model directly supports Engaged Learning through the five values of Consciousness of Self, Commitment, Collaboration, Controversy with Civility, and Citizenship.

Leadership educators often develop students' Consciousness of Self through the use of personality inventories and profiles - e.g. Gallup's StrengthsFinder (Rath, 2007), Myers-Briggs Type Indicator (Briggs-Myers, McCaulley, Quenk, \& Hammer, 1998) and True Colors (Miscisin $\&$ Haines, 2001). These also facilitate students engaging in their learning by connecting with their own lived experiences. This extends beyond students' courses in leadership studies to reflecting and better understanding themselves in other courses as well. Through activities like The Golden Circle (Sinek, 2009), when students develop their value of Commitment they again are able to persist through academic difficulties because they understand the connection to their own lives and are resolved to working toward their desired academic outcomes.

Students who value Collaboration are more engaged learners in group activities. Collaboration is developed through teambuilding activities such as those that use Strengths Based Leadership where students use each others' strengths to build up their team (Rath \& Conchie, 2009). Whether on assigned class teams or ad-hoc study groups, these students recognize the importance of collaborative efforts and actively work to recognize the value the contributions of each group member - and therefore more actively participating and engaging with peers in learning.

Also in the Social Change Model's group dimension, learning Controversy with Civility develops students' understanding of their own lives and the perspectives of others with whom they disagree. A frequently used activity that facilitates students learning this value is Take a Stand, with many variations adaptable to the participants (Facing History and Ourselves, 2014). Controversy with Civility challenges students to be practice Engaged Learning as they seek to navigate disagreements constructively, understand alternative viewpoints, and reconsider their own beliefs. 
Finally, the value of Citizenship within the Social Change Model helps students connect what they are learning not only with their own lives but with the community and the society in which they live, which supports Engaged Learning. To support these connections and reframe stereotyping, many leadership educators share Chimamanda Adichie's TED talk (2009) and build on her message to support students in engaging more intentionally with members of their community.

Diverse citizenship. This factor is marked by a strong curiosity in students, a readiness to learn from the lived experiences of other people. Contrary to the prior factor, Engaged Learning which focuses on connecting learning to students' own lives, Diverse Citizenship focuses on connecting their learning through other people in their lives, including multiple cultures, interests, and perspectives. The Social Change Model supports this factor through five values: Consciousness of Self, Congruence, Common Purpose, Controversy with Civility, Citizenship.

First, when developing Consciousness of Self and Congruence, students gain a greater awareness of their prior learned pre-dispositions, including biases and tendencies of which they were unaware. This awareness feeds their curiosity to learn more from others around them. Activities that support this increased awareness include Project Implicit (Greenwald, Banaji, \& Nosek, 2011) and Social Identities Awareness (Blumenfeld, 2011).

Learning to value and practice Common Purpose propels students to seek out what they share in common with people who have different lived experiences than themselves. Controversy with Civility develops students' skills to understand differing perspectives and learn from them. Further, Citizenship challenges students to value the diversity of individuals that comprise their communities. These three values are addressed through activities like Sailing the Seven C's (Wagner, Ostick, \& Komives, 2007) and Lollipop Moments in Leadership (Mushili, 2012) that challenge students to appreciate the lived experiences of people around them.

Social Connectedness. Also contributing to a sense of community is the factor of Social Connectedness. This factor envelopes strong, positive relationships in students' lives with whom they can discuss their own challenges and successes. The Social Change Model supports this factor through the four values of Consciousness of Self, Congruence, Controversy with Civility, and Citizenship.

At the individual dimension, students learn Consciousness of Self through activities like Johari's Window (Luft, 1984) that emphasize the social bonds made through self-disclosure. Studying Congruence through the one's sphere of influence challenges students to identify with whom they have positive, supportive relationships and how to expand that sphere. Further, studying the values of Controversy with Civility and Citizenship contribute to students skills in strengthening the social ties they have and valuing the social community of people in their lives that support them. These four values reinforce for students their social bonds and they provides students with tools to expand and strengthen their social network, which serves the Thriving factor of Social Connectedness.

Positive Perspective. Students' optimism and long-term view of events is reflected in this Thriving factor. Taking a positive perspective on setbacks - such as framing a low grade on 
a first test as a motivator to study more for the remaining tests - goes a long way in students recovering from such setbacks. The Social Change Model contributes to students' Positive Perspectives through the values of Consciousness of Self, Congruence, Collaboration, and Citizenship.

In the individual dimension, Consciousness of Self and Congruence are strengthened through regular reflection activities, such as daily Three Good Things (Seligman, Steen, Park, \& Peterson, 2005) and Leadership Barometer (Hershey, 2007). Recognizing that teams go through predictable stages that students can influence is advanced when learning the value of Collaboration by studying Tuckman and Jensen's Stages of Small-Group Development (1977). Finally, the value of Citizenship contributes to students' Positive Perspective when studying Greenleaf's Servant Leadership theory and how all members in a community can lead each other through service (Autry, 2007; Greenleaf \& Spears, 2002). From the Social Change Model's four values here, students develop a greater Positive Perspective on their experiences.

Of the 5 factors of the Thriving Model and 7 values of the Social Change Model, there are 35 intersections between the models. Above we laid out the connection of 22 points of the 35 intersections. Further work may be able to contribute how the missing 13 points are fulfilled. But these 22 points already demonstrate a strong support of the Thriving Model by the Social Change Model. This connection is important because of how it demonstrates that studying leadership, at least through the Social Change Model, has the potential to substantially contribute to students' success in college as measured by the Thriving Model.

\section{Implications for Practice}

This article outlines how learning leadership can significantly contribute to students' success in college and beyond. With this, there are a number of implications for practitioners and program coordinators to consider. Coursework in leadership education should be accessible to students early in their collegiate career. Efforts should be made to enroll students who are particularly at risk of struggling or departing early from college. Supporting student service programs with leadership development activities also is key to maximizing shared goals for student success.

Leadership studies classes should be offered early in students' collegiate careers. Developing new students' own leadership abilities is a vehicle for helping them learn to lead themselves and to thrive in college. Leadership classes early in the collegiate years will contribute to a successful transition to college. As our field of leadership studies expands we need to focus on teaching leadership early, especially the first semester, to enable students to lead themselves and their peers through college. This magnifies the positive outcomes of leadership studies classes.

Reach out to students who are more likely to struggle in college. The capacity of leadership studies classes to substantively shift students' likelihood of thriving in college should also inform the subpopulations of students we recruit to take courses in leadership. The students with strong leadership experiences in high school (e.g. team captain, valedictorian, yearbook editor) are coming in already with a high likelihood of thriving in college. Leadership educators 
can contribute to increasing students' Thriving Quotient much more among the individuals who may be at risk, or have not yet realized their leadership potential and would benefit greatly from just one course in leadership studies. These students are who we as a field can most help andwith our limited resources - have an obligation to support first.

Building on this, partnering with other institutional programs that already support at-risk students should be a priority. These programs often provide leadership development training with their students. Partnering will strengthen both programs and better serve students. By way of example, many campuses offer student-led tutoring programs where tutors would benefit from enhancing their values in the Social Change Model's Consciousness of Self and Common Purpose. Campus programs targeted at supporting women and minorities in the fields of science, technology, engineering, and mathematics (STEM) would benefit from enhancing their students' values in the Social Change Model's Congruence, Commitment, and Collaboration. These are but a couple examples where partnering would be mutually beneficial, other partnerships might include: Trio services; transfer-student services; new-student programs; gay, lesbian, bisexual, and transgender student services; veteran student services; and multi-cultural student services. Such partnerships in the short term would benefit the first-year students through targeted transition to college and skill development. In the long term these partnerships build pathways for introducing students to the leadership studies program and increasing their likelihood to pursue further coursework in leadership studies to develop their leadership knowledge, skills, and attitudes in complement of their respective majors.

In addition to partnering with programs who serve students who might be considered atrisk, leadership studies programs must develop, maintain, and sustain partnerships with student engagement offices in their divisions of student affairs. These programs often provide valuable out of class leadership development experiences through all campus programming events, clubs, student government and fraternity and sorority life to name a few. The partnership can also include developing leadership studies courses with out-of-class components lead by the student engagement office. These activities could be in the form of a learning community, leadership workshops, leadership development speakers, and retreats. This partnership is most beneficial when the leadership studies foundational frameworks align with the student engagement offices foundational frameworks for program development, i.e. the Social Change Model.

Finally, leadership educators should thoroughly assess outcomes of students participating in leadership studies programs. The high potential for positive outcomes should not be assumed, but rigorously measured and shared with key constituents. Increasing student persistence and achievement is a persistent challenge in higher education. Stakeholders would be highly interested in programs that demonstrate results in addressing these challenges, including administrators, policy makers, parents, alumni, and donors.

\section{Further Research}

Empirically research is needed to measure the contributions of leadership education to first-year students thriving in college. Along with development of the Thriving Model, Schreiner and her research team have developed a survey instrument to measure the five factors and calculate a Thriving Quotient for students (Schreiner et al., 2013). The researchers 
psychometrically validated the instrument and demonstrated its usefulness in predicting desirable outcomes of persistence, graduation, and satisfaction. But no research to date has been published on how college students' Thriving Quotient is directly affected by the development of their leadership abilities. To contribute to leadership educators' understanding of these relationships, rigorous causal-model studies are needed. This will allow for recommendations of best practices in pedagogy for leadership education programs.

Qualitative research is needed to understand students' experiences more deeply. These studies - using individual interviews and focus groups - should focus on several sub-sets of students. Of early interest are students who demonstrated the greatest gains in the quantitative surveys. Interviews with these students would help identify the key experiences that changed their trajectory. Further, these students had significant interactions with faculty and staff who would have additional insights to contribute from their observations on how key experiences affected the students.

In the same vein but from the contrary perspective, research is needed with students who had similar pre-test scores as those high-gain students but did not appreciably change in their post-test scores. This would help differentiate why the key experiences did not affect them in similar ways. What contributed to these students not gaining? What can leadership educators do differently to contribute to these students' thriving in college? Additionally, understanding if there are demographic implications for students' experiences that contribute to their Thriving Quotient. For example does gender, race, class, sexual orientation, veteran status, or international-student status contribute to who gains and how? Further, do the intersections of identities contribute to how students experience leadership education and thus gain in the Thriving Quotient? These lines of inquiry are best explored qualitatively and will inform our field's understanding of how leadership studies contributes to students thriving in college and beyond.

Qualitative data collection can also allow for interviewing faculty and staff outside of the leadership studies program who see growth in the student through the thriving quotient. This type of data collection from those who interact with students through their college career can allow for a further understanding of cognitive and interpersonal development in college and the further implications of leadership education to students thriving in college.

This research is vital to the ongoing curriculum development of leadership studies programs. It will contribute to our field's understanding of how students are affected by leadership education and do so with respect to key outcomes of student persistence and achievement. This knowledge will inform both curriculum design and allocation of limited resources to maximize the gains with students who will realize the most benefit.

\section{Conclusion}

By intersecting the Social Change Model and the construct of the Thriving Model, leadership studies programs can develop intentional curriculum that contributes to not only students developing their leadership abilities, but to student success through growth academically and personally. These latent effects can be leveraged by leadership studies programs to increase 
the positive good they are doing on campuses. Intentional curriculum development using the intersecting models can be measured and catered for specific student needs in order for the student to make gains using the Thriving Quotient. Campus partners can be supportive in recruiting specific students who will benefit from experiencing leadership studies courses that focus on thriving and student success. More work is needed to document students' gains and the pathways through which these transformations manifest in students' persistence and academic achievement. But clearly leadership studies programs can play a key role in first-year student transition and offer opportunities for academic growth and personal development early on in the college career to maximize student success.

\section{References}

Adichie, C. (2009). The danger of a single story. Retreived from http://www.ted.com/talks/chimamanda_adichie_the_danger_of_a_single_story.html

Autry, J. A. (2007). The servant leader: How to build a creative team, develop great morale, and improve bottom-line performance. New York, NY: Crown Publishing Group.

Blumenfeld, W. J. (2011). Social identities worksheet. Ames, IA: Iowa State University.

Briggs-Myers, I., McCaulley, M. H., Quenk, N. L., \& Hammer, A. L. (1998). MBTI manual: A guide to the development and use of the myers-briggs type indicator. Mountain View, CA: Consulting Psychologists Press.

Facing History and Ourselves. (2014). Barometer: Taking a stand on controversial issues. Retrieved from https://www.facinghistory.org/for-educators/educatorresources/teaching-strategies/barometer-taking-stand-contro

Greenleaf, R. K., \& Spears, L. C. (2002). Servant leadership: A journey into the nature of legitimate power and greatness. Mahwah, NJ: Paulist Press.

Greenwald, T., Banaji, M., \& Nosek, B. (2011). Project implicit. Retrieved from https://www.projectimplicit.net/index.html

Hershey, K. (2007). An introduction to leadership. In J. E. Owen, Komives, S. R., Lucas, N., \& McMahon, T. R. (Ed.), Instructor's guide for exploring leadership: For college students who want to make a difference: Retreived from http://www.nclp.umd.edu/include/pdfs/publications/exploringleadershipguide.pdf.

Higher Education Research Institute. (1996). A social change model of leadership development: Guidebook version III. College Park, MD: National Clearinghouse for Leadership Programs.

Hull-Blanks, E., Kurpius, S. E. R., Befort, C., Sollenberger, S., Nicpon, M. F., \& Huser, L. (2005). Career goals and retention-related factors among college freshmen. Journal of Career Development, 32(1), 16-30. 
Keyes, C. L. M., \& Haidt, J. (2003). Flourishing: Positive psychology and the life well-lived. Washington, DC: American Psychological Association.

Kezar, A. J., Carducci, R., \& Contreras-McGavin, M. (2006). Rethinking the " $L$ " word in higher education: The revolution of research on leadership: ASHE higher education report. Hoboken, NJ: John Wiley \& Sons.

Luft, J. (1984). Group processes: An introduction to group dynamics. Mountain View, CA: Mayfield Publishing Company.

Miscisin, M., \& Haines, J. (2001). Showing our true colors: A fun, easy guide for understanding and appreciating yourself and others. Riverside, CA: True Colors.

Mushili, M. (2012). Lollipop moments in leadership. Retreived from http://www.philambdasigma.org/LinkClick.aspx?fileticket=YofP7EKvgIE\%3D\&tabid=1 770

Owen, J. E. (2012). Using student development theories as a conceptual framework in leadership education. In K. Guthrie \& L. Osteen (Eds.), Developing student leadership capacity (pp. 17-36). San Francisco, CA: Jossey-Bass.

Quoidbach, J., Wood, A. M., \& Hansenne, M. (2009). Back to the future: The effect of daily practice of mental time travel into the future on happiness and anxiety. The Journal of Positive Psychology, 4(5), 349-355.

Rath, T. (2007). Strengths finder 2.0. New York, NY: Gallup Press.

Rath, T., \& Conchie, B. (2009). Strengths based leadership. New York, NY: Gallup Press.

Reardon, J. (2003). Trouble on the bridge. Paper presented at the Interest Based Training for the State of Iowa Public Employee Relations Board, Waterloo, IA.

Schreiner, L. A. (2010a). Thriving in community. About Campus, 15(4), 2-11.

Schreiner, L. A. (2010b). Thriving in the classroom. About Campus, 15(3), 2-10.

Schreiner, L. A. (2010c). The "Thriving Quotient": A new vision for student success. About Campus, 15(2), 2-10.

Schreiner, L. A. (2013). Thriving in college. New Directions for Student Services, 143, 41-52.

Schreiner, L. A., McIntosh, E. J., Kalinkewicz, L., \& Cuevas, A. E. P. (2013). Measuring the malleable: Expanding the assessment of student success. Paper presented at the Assocation for the Study of Higher Education, St. Louis, MO.

Schreiner, L. A., McIntosh, E. J., Nelson, D., \& Pothoven, S. (2009). The thriving quotient: Advancing the assessment of student success. Paper presented at the Association for the Study of Higher Education, Vancouver, BC. 
Seligman, M. E. P. (2002). Authentic happiness: Using the new positive psychology to realize your potential for lasting fulfillment. New York, NY: Free Press.

Seligman, M. E. P. (2011). Flourish: A visionary new understanding of happiness and wellbeing. New York, NY: Free Press.

Seligman, M. E. P., \& Csikszentmihalyi, M. (2000). Positive psychology: An introduction. American Psychologist, 55(1), 5-14.

Seligman, M. E. P., Steen, T. A., Park, N., \& Peterson, C. (2005). Positive psychology progress: Empirical validation of interventions. American Psychologist, 60(5), 410.

Sinek, S. (2009). Start with why: How great leaders inspire everyone to take action. New York, NY: Penguin Group.

Suddendorf, T., \& Busby, J. (2005). Making decisions with the future in mind: Developmental and comparative identification of mental time travel. Learning and Motivation, 36(2), $110-125$.

Tuckman, B. W., \& Jensen, M. A. C. (1977). Stages of small-group development revisited. Group \& Organization Management, 2(4), 419-427.

Wagner, W., Ostick, D. T., \& Komives, S. R. (2007). Leadership for a better world:

Understanding the social change model of leadership development instructor's manual. San Francisco, CA: Jossey-Bass.

\section{Author Biographies}

Clinton M. Stephens serves as a lecturer for leadership education with the Carrie Chapman Catt Center for Women and Politics at Iowa State University. Stephens coordinates the Catt Center's leadership studies program, teaches classes in leadership studies, and conducts research on assessing the effectiveness of courses and workshops to develop college students' leadership abilities. Stephens completed a B.S. in Business Administration at Kansas State University in 2002, a M.S. in College Student Development at Oklahoma State University in 2005 and a Ph.D. in Higher Education Administration in 2012 at Iowa State University.

Cameron C. Beatty, lecturer in leadership education and program adviser for the leadership studies program with the Carrie Chapman Catt Center for Women and Politics at Iowa State University. He graduated in August 2014 from Iowa State University with a Ph.D. in higher education administration. He earned a master's degree in higher education student affairs and a bachelor's degree in sociology and African and African American diaspora studies, both from Indiana University. His doctoral dissertation focused on exploring the leadership identity development of students of color at a liberal arts college. Beatty's particular areas of interest include such topics as definitions of masculinity, student affairs research, engaging students of color, black student leaders and team advising. 